\title{
Response of Whole Blood, Erythrocyte and Plasma Vitamin E Content to Dietary Vitamin E Intake in the Chick
}

\author{
By Saifeldin Hassan and Juhani Hakkarainen
}

Department of Clinical Nutrition, College of Veterinary Medicine, Swedish University of Agricultural Sciences, Uppsala, Sweden.

\begin{abstract}
Hassan, S. and J. Hakkarainen: Response of whole blood, erythrocyte and plasma vitamin $E$ content to dietary vitamin $E$ intake in the chick. Acta vet. scand. 1990, 31, 399-408. - Whole blood, red blood cells (RBC), and plasma vitamin E (VE) levels in chicks fed dietary VE (dl- $\alpha$-tocopheryl acetate, dl- $\alpha \mathrm{Ta}$ ) supplementation in steps of $0.0,5.0,10.0,15.0,20.0$ and $30.0 \mathrm{mg} / \mathrm{Kg}$ were determined to examine their usefulness as an index of VE status. The increase in VE level was significant and linear in whole blood $(r=0.90), R B C(r=0.89)$ and plasma $(r=0.93)$ in response to dietary VE intake. There was a close correlation between VE in plasma vs whole blood $(\mathrm{r}=0.90)$, plasma vs $\mathrm{RBC}(\mathrm{r}=0.91)$ and whole blood vs $\mathrm{RBC}(\mathrm{r}=$ 0.95 ). The plasma VE content was 1.2-1.8 times greater than that of whole blood, and 6.6-12.5 times greater than that of RBC. The plasma total lipids content was not affected by the dietary VE intake, whereas the level of VE in the plasma total lipids was significantly increased with increasing supplementation. Alpha tocopherol was the major isomer (ca $92 \%$ ) of VE in whole blood, RBC and plasma at hatching. The small proportions of $\beta$-tocopherol (ca $2 \%$ ), $\gamma$-tocopherol (ca $5 \%$ ) and $\alpha$-tocotrienol (ca $1 \%$ ) observed at 1 day of age had decreased or totally disappeared by 7 days of age after feeding the VE-free basal diet. The data showed that in the chick, the whole blood and RBC levels of VE were as sensitive and reliable indexes of dietary VE status as was that of the plasma.
\end{abstract}

$\alpha$-tocopherol; $\beta$-tocopherol; $\gamma$-tocopherol; dl- $\alpha$-tocopheryl acetate; plasma total lipids.

\section{Introduction}

Vitamin E (VE) and selenium are well-recognized as being important components of the cell membrane defense system against peroxidative damage (Hoekstra 1975). Noguchi et al. (1973) reported that the plasma membrane in chicks was the site of the biological action of VE, where it neutralizes free radicals, preventing the development of exudative diathesis. Red blood cell (RBC) membranes deficient in VE are susceptible to hemolysis, and maintenance of the integrity of the RBC membrane partially de- pends on an adequate VE status (Rose \& Gyorgy 1950).

Vitamin $\mathrm{E}$ is widely distributed in human and animal tissues, with appreciable amounts stored in the liver (Gallo-Torres 1980). The assessment of VE status in different species may be determined by the direct measurement of the VE content in a specific tissue, which is then assumed to reflect the whole body VE status. Early studies with mammals used the plasma and liver VE contents as an index. However, the validity of using the plasma VE content was 
questioned by Horwitt et al. (1972), who found that it increased in response to an increase in the level of the plasma lipids. These workers concluded that VE/total lipids ratio in plasma would be the best index of the vitamin status. Recently, Vatassary et al. (1983) suggested that the level of VE in the platelet was a reliable index of VE status in human. In rats, the use of RBC as indicator of the VE status was supported by Mino et al. (1985). However, Lehmann (1984) found that VE level in the platelets, but not in the $\mathrm{RBC}$, was the best index of VE status of these animals.

With respect to avians, primarily the chick, the plasma and liver VE levels have been used as indicators of VE biopotency and status (Pudelkiewicz et al. 1960, Scott \& Desai 1964, Hakkarainen et al. 1984). A linear increase in plasma and liver VE levels in chicks in response to dietary supplementation was observed by Hakkarainen et al. (1984). However, studies on the comparative responses of whole blood, RBC and plasma to dietary VE intake in the chick are lacking. Apparently, less attention has been focused on the whole blood and RBC content of VE in various species due to technical difficulties with the assay. However, recent progress in VE analyses employing high performance liquid chromatography (HPLC) have facilitated the accurate determination of VE content in RBC.

The present study was undertaken in order to compare the validity of using whole blood, RBC and plasma VE concentrations in the chick as an index of dietary VE intake. The chicks were fed graded levels of $\mathrm{VE}$ as dl- $\alpha$-tocopheryl acetate (dl- $\alpha \mathrm{Ta})$, while the dietary fat was kept constant. HPLC was used for the VE assay, and a method for the analyses of whole blood and erythrocyte VE in the chick is described.

\section{Material and methods}

Commercial White Leghorn male chicks were used for the present study. At hatching, 6 chicks were immediately selected at random. Whole blood samples were obtained by cardiac puncture and they were then sacrificed. For 1 week after hatching, 19 groups of 10 chicks each were fed a VE-free basal diet containing all other nutrients required by the chick. This diet consisted of casein, 9.5\%; gelatin, $11.5 \%$; skim-milk powder, $16.5 \%$; cellulose, $3.0 \%$; glucose, $44.94 \%$; distilled fatty acids obtained from soybean oil, $3.0 \%$; amino acid mixture, $0.96 \%$; mineral mixture, $5.6 \%$ and vitamin mixture, $5.0 \%$. For descriptions of the amino acid, mineral and vitamin mixtures, see Hassan et al. (1987). Adequate amounts of selenium (as sodium selenite) and ethoxyquin were included in the basal diet to protect the chicks against VE and/or Se deficiency. At 7 days of age, whole blood was again collected from 6 chicks in 1 group, and the remainder of the chicks in this group were destroyed. The VE depletion period was followed by a 6 week repletion period, during which the basal diet was supplemented with $0.0,5.0,10.0,15.0,20.0$ or $30.0 \mathrm{mg} \mathrm{VE}$ as dl- $\alpha \mathrm{Ta} / \mathrm{kg}$ (Vitamin E dry powder, $50 \%$, Rovimix E-50 SE, F. Hoffmann-La Roche).

Each dietary treatment and water were provided to 3 groups of chicks ad lib. The chicks were housed in electrically heated wire batteries, and were wing banded. The relative humidity was ca $65 \%$ and artificial light was provided $24 \mathrm{~h} /$ day. At the end of the study, 6 chicks per treatment ( 2 per group) were selected at random for whole blood sampling.

Heparinized tubes were used to obtain whole blood by cardiac puncture from chicks killed at 1, 7 and 49 days of age. Each 
sample was divided into 2 portions. One portion was immediately stored at $-70^{\circ} \mathrm{C}$, and the other was centrifuged at $2500 \times \mathrm{g}$ for 10 min to obtain plasma. The packed RBC were washed 3 times with buffer sulphate (pH 7.4). After the last washing, care was taken to obtain exactly the same volume of the whole blood noted prior to storage.

The determination of VE in whole blood and RBC was carried out using a modification of the method reported by Stump et al. (1984). Two $\mathrm{ml}$ ice cold methanol containing $1 \%$ pyrogallol was added slowly to $1 \mathrm{ml}$ $\mathrm{RBC}$ suspension or whole blood while carefully mixing (Vortex blender). Tocopherol was then extracted with a solution of $4 \mathrm{ml}$ hexane containing $0.1 \%$ butylated hydroxytoluene (BHT). Three $\mathrm{ml}$ of the hexane phase was evaporated under nitrogen gas flow at $30-35^{\circ} \mathrm{C}$. The residue was then dissolved in $150 \mu \mathrm{l}$ of heptane, and $20 \mu \mathrm{l}$ were used for the manual loop injection. For plasma VE analysis, protein precipitation and extraction were done as reported by Hakkarainen et al. (1984). Mean recoveries of 8 analysed samples of whole blood or RBC and 4 of plasma, were 98,97 and $97 \%$, respectively, while the corresponding values for the coefficient of variation (CV) were $2.8,1,6$ and $1.1 \%$, respectively. The solution was injected into a Merck Hibar 125-4 $(5 \mu \mathrm{m})$ silica column held thermostatically at $37^{\circ} \mathrm{C}$. The mobile phase contained $6 \%$ ether in heptane. The flow rate during elution was $1.3 \mathrm{ml} / \mathrm{min}$, and the retention time for $\alpha$-tocopherol $(\alpha-T), \alpha$-tocotrienol $(\alpha-\mathrm{T} 3)$, $\beta$-tocopherol $(\beta-\mathrm{T})$ and $\gamma$-tocopherol $(\gamma-\mathrm{T})$ were $5.3,7.1,8.6$ and $10.2 \mathrm{~min}$, respectively. The Perkin-Elmer HPLC system consisted of a model PE Series 10 pump module, fitted with a $20 \mu \mathrm{l}$ sample loop. Plasma total lipids content was analysed according to Epstein et al. (1972).

Statistical analyses of the data were perfor- med by linear regression (Finny 1978) and analyses of variance (Dunn \& Clark 1974) using the GLM procedure of the SAS computer programs (Statistical Analyses System 1985).

\section{Results}

The initial VEs level in the whole blood, $\mathrm{RBC}$ and plasma of chicks at hatching were $48.06 \pm 7.12,8.17 \pm 1.13$ and $62.48 \pm 3.65$ $\mathrm{mg} / \mathrm{ml}$, respectively. Feeding the VE-free basal diet without supplementation to chicks for the first week posthatching significantly $(p<0.01)$ reduced the 1 day of age VE levels to $9.15 \pm 2.43,0.17 \pm 0.05$ and $12.54 \pm 1.75$ $\mathrm{mg} / \mathrm{ml}$, respectively. The effect of dietary VE supplementation as $\mathrm{dl}-\alpha \mathrm{Ta}$ for 6 weeks on VE levels in whole blood and blood components, and on plasma total lipids content and their VE concentrations is presented in Table 1. Observations at the end of the repletion period showed significantly $(p<0.01)$ lower levels of VE in whole blood, RBC and plasma of chicks without VE supplementation in comparison to those found at 7 days of age. Supplementation of 5.0 or more mg VE $(\mathrm{dl}-\alpha \mathrm{Ta}) / \mathrm{Kg}$ diet led to significant $(p<0.05)$ increases in whole blood, RBC and plasma levels of VE in comparison to those in the control chicks. With each increment in dietary VE supplementation, there was a further slight or significant $(p<0.05)$ increase in the VE levels of the whole blood and blood components. At each supplemental level, slightly or significantly $(\mathrm{p}<0.05)$ higher concentrations of VE were found in the plasma in comparison to those in the whole blood, whereas the levels of VE in RBC were constantly lower $(p<0.05)$ than those of whole blood and plasma.

The VE content of the plasma total lipids decreased significantly $(\mathrm{p}<0.01)$ from $18.10 \pm 1.74$ at hatching to $3.11 \pm 0.25 \mathrm{mg} / \mathrm{g}$ 
Table 1. Effect of dietary vitamin $E$ supplementation on the vitamin $E$ level in whole blood, erythrocytes (RBC), plasma and plasma lipids, and on the plasma content of total lipids in the chick' ${ }^{1}$.

\begin{tabular}{|c|c|c|c|c|c|c|}
\hline \multirow{3}{*}{ Diet } & \multirow{3}{*}{$\begin{array}{c}\text { Dietary VE } \\
\text { supplement } \\
\mathrm{mg} / \mathrm{kg}^{2}\end{array}$} & \multicolumn{5}{|c|}{ Vitamin $E$ content } \\
\hline & & \multirow{2}{*}{$\begin{array}{l}\text { Whole blood } \\
\mathrm{mg} / \mathrm{ml}\end{array}$} & \multirow{2}{*}{$\begin{array}{c}\mathrm{RBC} \\
\mathrm{mg} / \mathrm{ml}\end{array}$} & \multirow{2}{*}{$\begin{array}{l}\text { Plasma } \\
\mathrm{mg} / \mathrm{ml}\end{array}$} & \multicolumn{2}{|c|}{ Plasma lipids } \\
\hline & & & & & $\mathrm{mg} / \mathrm{g}$ & $\mathrm{g} / 1$ \\
\hline 1 & 0.00 & $0.48 \pm 0.14^{a, 3,4}$ & $0.07 \pm 0.02^{\mathrm{a}}$ & $0.78 \pm 0.18^{a}$ & $0.16 \pm 0.03^{a}$ & $4.36 \pm 0.24^{\text {n.s. }}$ \\
\hline 2 & 5.00 & $1.11 \pm 0.09 \mathrm{~b}$ & $0.17 \pm 0.04^{b}$ & $1.43 \pm 0.11^{\mathrm{b}}$ & $0.35 \pm 0.02^{b}$ & $4.19 \pm 0.27$ \\
\hline 3 & 10.00 & $1.48 \pm 0.15^{\mathrm{b}}$ & $0.39 \pm 0.09^{c}$ & $2.61 \pm 0.32^{c}$ & $0.69 \pm 0.07 \mathrm{c}$ & $4.15 \pm 0.28$ \\
\hline 4 & 15.00 & $3.36 \pm 0.54^{\mathrm{c}}$ & $0.49 \pm 0.06^{\mathrm{d}}$ & $3.98 \pm 0.37^{d}$ & $1.12 \pm 0.08^{d}$ & $4.06 \pm 0.38$ \\
\hline 5 & 20.00 & $3.96 \pm 0.50^{\mathrm{d}}$ & $0.67 \pm 0.08^{d}$ & $4.81 \pm 0.57 \mathrm{e}$ & $1.26 \pm 0.14^{d}$ & $4.09 \pm 0.23$ \\
\hline 6 & 30.00 & $5.05 \pm 0.53^{e}$ & $0.83 \pm 0.14^{f}$ & $6.33 \pm 0.88^{f}$ & $1.65 \pm 0.23^{e}$ & $4.13 \pm 0.31$ \\
\hline
\end{tabular}

${ }^{1}$ Prior to a repletion period of 6 weeks, the chicks were depleted of VE for 1 week. ${ }^{2}$ Supplemented as dl- $\alpha \mathrm{Ta} .{ }^{3}$ Means \pm SD of 6 observations per treatment. ${ }^{4}$ Means within a column with different lower case superscripts are significantly different (with at least $p<$ $0.05)$. ${ }^{n . s .}$ The effect of the treatments was not significant $(p>0.05)$.

lipids at 7 days of age in response to VE depletion. As shown in Table 1, there was no effect $(p>0.05)$ of dietary VE supplementation on the plasma total lipids content at 7 weeks of age. However, the VE level in the plasma total lipids increased numerically or significantly $(p<0.05)$ with each increment in VE supplementation.

Over the present VE supplemental range $(5.0-30.0 \mathrm{mg} / \mathrm{Kg})$ there was a linear increase in the VE content of the whole blood, RBC, plasma, and plasma lipids $v s$ dietary VE intake (Table 2 ). In addition, a strong positive correlation between the VE levels in plasma vs whole blood, plasma vs RBC and whole blood vs RBC were observed (Table 2). Calculations of the ratios of VE levels in plasma vs whole blood and plasma vs RBC (unpresented data), showed clear trend for lower ratios with increasing supplementation.

The per cent distribution of the VE isomers in whole blood, RBC and plasma at 1 and 7 days of age is given in Table 3. At hatching, $\alpha-\mathrm{T}$ comprised $92 \%$ of the total VE content, $\gamma$-T was ca $5 \%$ while $\beta$-T and $\alpha$-T3 were observed in lesser amounts (ca $2.8 \%$ ). After

Table 2. Relationship between vitamin E levels in the whole blood, erythrocytes, plasma and plasma lipids vs dietary vitamin $\mathrm{E}$ supplement, and between vitamin $\mathrm{E}$ level in plasma vs whole blood, plasma vs erythrocytes and whole blood $v s$ erythrocytes in chicks at 7 weeks of age.

\begin{tabular}{llll}
\hline Response variable $(\mathrm{Y})$ & Exposure variable $(\mathrm{X})$ & \multicolumn{2}{c}{ Linear regression equation } \\
\hline Whole blood VE content & Dietary VE content & $\mathrm{Y}=0.39+0.16 \mathrm{X}, \mathrm{r}=0.90$ & $\mathrm{p}<0.001$ \\
Erythrocyte VE content & Dietary VE content & $\mathrm{Y}=0.08+0.03 \mathrm{X}, \mathrm{r}=0.89$ & $\mathrm{p}<0.001$ \\
Plasma VE content & Dietary VE content & $\mathrm{Y}=0.73+0.19 \mathrm{X}, \mathrm{r}=0.93$ & $\mathrm{p}<0.001$ \\
Plasma lipids VE content & Dietary VE content & $\mathrm{Y}=0.18+0.05 \mathrm{X}, \mathrm{r}=0.92$ & $\mathrm{p}<0.001$ \\
Plasma VE content & Whole blood VE content & $\mathrm{Y}=0.14+0.82 \mathrm{X}, \mathrm{r}=0.90$ & $\mathrm{p}<0.001$ \\
Plasma VE content & Erythrocyte VE content & $\mathrm{Y}=0.03+0.12 \mathrm{X}, \mathrm{r}=0.91$ & $\mathrm{p}<0.001$ \\
Whole blood VE content & Erythrocyte VE content & $\mathrm{Y}=0.03+0.15 \mathrm{X}, \mathrm{r}=0.95$ & $\mathrm{p}<0.001$ \\
\hline
\end{tabular}


Table 3. The relative per cent distribution of the tocopherol and tocotrienol isomers in the whole blood, erythrocyte (RBC) and plasma of chicks at hatching and at 7 days of age ${ }^{1}$.

\begin{tabular}{lccccc}
\hline & & \multicolumn{4}{c}{ Relative percentage of isomer distribution (\%) 2} \\
\cline { 3 - 6 } $\begin{array}{l}\text { Tissue } \\
\text { site }\end{array}$ & $\begin{array}{c}\text { Age } \\
\text { (days) }\end{array}$ & \multicolumn{1}{c}{$\alpha-\mathrm{T}$} & $\beta-\mathrm{T}$ & $\gamma-\mathrm{T}$ & $\alpha-\mathrm{T} 3$ \\
\hline Whole blood & 1 & $91.82 \pm 0.76^{3}$ & $1.94 \pm 0.26$ & $5.11 \pm 0.85$ & $0.84 \pm 0.13$ \\
RBC & 1 & $92.45 \pm 0.21$ & $1.93 \pm 0.14$ & $4.96 \pm 0.17$ & $0.71 \pm 0.10$ \\
Plasma & 1 & $92.75 \pm 0.24$ & $1.87 \pm 0.06$ & $4.59 \pm 0.21$ & $0.79 \pm 0.09$ \\
Whole blood & 7 & $99.01 \pm 0.30$ & - & $0.99 \pm 0.29$ & - \\
RBC & 7 & $100.00 \pm 0.00$ & - & - & - \\
Plasma & 7 & $99.18 \pm 0.57$ & - & $0.82 \pm 0.36$ & - \\
\hline
\end{tabular}

${ }^{1}$ Chicks were fed a VE-free basal diet for 7 days posthatching. ${ }^{2} \alpha$-T: $\alpha$-tocopherol, $\beta$-T: $\beta$-tocopherol, $\gamma$-T: $\gamma$-tocopherol, $\alpha$-T3: $\alpha$-tocotrienol. ${ }^{3}$ Mean \pm SD of 6 observations.

the depletion period, none of $\beta$-T and $\alpha$-T3 isomers could be detected at 7 days of age, only trace amounts of $\gamma$-T were found in the plasma and whole blood, while the proportion of $\alpha-T$ had increased $(\geq 99 \%)$. By the end of this study, $\alpha-\mathrm{T}$ was the sole isomer that could be detected in the various chick groups.

\section{Discussion}

The high VE content in the plasma and RBC of newly hatched chicks indicated that there had been an efficient carry over of VE from the mothers to their progeny. Immediate $V E$ depletion led to a rapid decrease in the VE concentration by 7 days of age. The percentage of the VE levels observed at hatching remaining after the depletion period were in whole blood, $19 \%$; RBC, $2 \%$; plasma $20 \%$ and plasma lipids, $17 \%$. Thus, the loss in the RBC content of VE was proportionally more than that in the plasma. Mino et al. (1981) reported a similar pattern of decrease in plasma and RBC levels of VE in VE depleted rats. The present rapid deprivation of the VE reserves agreed with previous studies and may explain the observed sus- ceptibility of growing chicks to VE deficiency diseases at 2-3 weeks of age when fed a VE low diet after hatching (Hakkarainen et al. 1984, Hassan et al. 1985). Therefore, the present data showed that dietary VE supplementation was essential for chicks after hatching, regardless of their tissue reserves of VE at 1 day of age.

The continuous increase in VE levels observed in the 2 blood components with each increment in supplemental VE suggested that the plasma and $\mathrm{RBC}$ were sensitive to changes in the VE intake, and that their storage capacity was not saturated by the present supplemental range. This agreed with previous observations in rats (Lehmann 1981) and chicks (Hakkarainen et al. 1984) fed similar nutritional VE levels. The present findings that the plasma VE level increased linearly when chicks were fed graded nutritional levels of $\mathrm{dl}-\alpha \mathrm{Ta}$ confirmed the findings of Pudelkiewicz et al. (1960) and Hakkarainen et al. (1984) that the concentrations of VE in the plasma and liver showed a close relationship to the dietary natural and synthetic VE intake and its biopotency in the prevention of nutritional encephalomalacia in the chick. 
The assessment of VE status in animals may be based on the measurement of VE in a certain tissue (Gallo-Torres 1980), the erythrocyte hemolyses test (Horwitt et al. 1972), or the observation of clinical signs and pathological lesions of VE-deficiency specific disease (Scott \& Desai 1964, Hakkarainen et al. 1984). The present low concentrations of VE observed in the plasma and RBC of the unsupplemented chicks indicated that there had been an efficient mobilization of VE in both blood components during depletion. This is in accordance with observations in chicks fed encephalomalacia inducing diets (Hakkarainen et al. 1984) and rats maintained on a low VE and selenium basal diet (Hakkarainen et al. 1986).

In absolute values, the plasma showed the highest level of VE, irrespectively of the supplemental level. It was 1.2-1.8 times greater than that in the whole blood and 6.6-12.5 times higher than that in RBC. Equivalent VE contents in the plasma and RBC have been reported for rats (Poukka \& Bieri 1970) and a higher level of VE in the RBC than in the plasma was observed for rabbits (Kaludin 1963). Bieri et al. (1977) and Mino et al. (1985) noted that the RBC concentration of VE decreased with an increase in the plasma lipids contents in rats and children, respectively. Apparently, species differences and differences in the VE supplemental ranges may account for the discrepancies in the results.

The presence of $\alpha-\mathrm{T}, \beta-\mathrm{T}, \gamma-\mathrm{T}$ and $\alpha-\mathrm{T} 3$ isomers in the plasma and RBC of newly hatched chicks reflected the isomer composition of the diet fed to their dams, which was obviously transferred to the chicks. The observed isomers were proportionally equally distributed between the plasma and RBC. In the human, Mino et al (1979) found only $\alpha-\mathrm{T}$ in the RBC while both $\alpha-\mathrm{T}$ and $\gamma-\mathrm{T}$ were observed in the plasma. Alpha toco- pherol was shown in the present study to be the major isomer in both plasma and $\mathrm{RBC}$, accounting for ca $93 \%$ of the isomers at hatching and $\geq 99 \%$ at 1 and 7 weeks of age. Similar observations were made in the plasma and liver of chicks even though the dietary content of the non- $\alpha-\mathrm{T}$ isomers was ca $60 \%$ of the total dietary VE (Hakkarainen et al. 1984). It has been reported that VE depletion causes a rapid and drastic loss of the various isomers in the tissue of chicks (Hakkarainen et al. 1984) and minks (Työppönen et al. 1984), which agreed with the partial or total disappearance of $\alpha-T, \beta-T$, $\gamma-\mathrm{T}$ and $\alpha-\mathrm{T} 3$ observed in the chicks at 7 days of age in the present study. In addition, the same authors suggested that increasing the dietary intake of $\mathrm{dl}-\alpha \mathrm{Ta}$ will lead to an increase in the $\alpha$-T concentration with a decline in the levels of non- $\alpha-T$ isomers in animal tissue, probably due to a dilution effect of the increased tissue VE concentration of $\alpha-T$. This may partially explain the total disappearance of all isomers, with the exception of $\alpha-T$ in the RBC and the plasma, by the end of the present investigation. Peake et al. (1972) found that VE deprived rats lost tissue $\gamma$-T more rapidly than $\alpha-T$. Thus, low concentrations of the non- $\alpha-T$ isomers in animal tissues may reflect a high rate of turnover of these isomers into $\alpha-T$.

The present investigation demonstrated that there was a close relationship between the $\mathrm{VE}$ in plasma $v s$ whole blood, plasma $v s$ $\mathrm{RBC}$, and whole blood vs RBC. Similar findings were reported in rats (Ishibashi et al. 1977), while Cunningham \& Soares (1981) reported that the plasma and erythrocyte ghost VE content in chicks were not well correlated. On the other hand, Lehmann (1981) suggested that RBC and plasma VE are not directly related, since the $\mathrm{RBC}$ content of VE is independent of the plasma total lipids which affect the plasma 
VE levels. The fact that the plasma VE level may be predicted from the RBC VE concentration and vice versa, as shown here, strengthens the validity of using the 2 blood compartments as indicators of this vitamin in the chick.

The level of the plasma total lipids in the present experimental chicks was not affected by the dietary intake of VE. Available reports regarding the effect of VE supplementation on the level of the plasma total lipids are contradictory. Increased (Lehmann 1981), lowered (Yang \& Dessi 1977) and no effect of VE (Aflin-Slater 1960) supplementation on the amount of rat plasma total lipids has been observed. A standard amount of dietary fat was provided in the present treatments, and similar levels of plasma total lipids were observed in the various chick groups. Therefore, it was not possible to determine or to speculate whether the RBC and/or the plasma VE content was affected by the plasma lipids level in the chick. It has also been observed that obese rats have a plasma total lipids and $\alpha$ - $T$ concentrations which are 3 times those of normal rats with the same intake of $\alpha$-T (Bieri \& Evarts 1975). The linear increase of the VE level in the plasma lipids in response to dietary dl- $\alpha$ Ta supplementation, as observed in this study, indicated that the plasma lipids content of VE may be used as an index of VE status when chicks are kept at a constant level of dietary fat intake.

It was shown in the present study that VE levels in whole blood, RBC and plasma were similarly sensitive to dietary dl- $\alpha \mathrm{Ta}$ supplementation in the range of $5.0-30.0 \mathrm{mg} / \mathrm{kg}$. A close correlation between VE concentration in plasma vs whole blood, plasma vs RBC and whole blood vs RBC was demonstrated. Plasma lipids concentration was not affected by dietary VE intake. Alpha tocopherol was the dominant isomer in both the plasma and the RBC. It was concluded that VE levels in plasma, whole blood and RBC were similarly valid as indicators of the VE status in the chick.

\section{Acknowledgements}

The authors are grateful to Ms. Marie Stråhle, for excellent laboratory assistance. This investigation was supported by grants from the Swedish Council for Forestry and Agricultural Research.

\section{References}

Aflin-Slater RB: Relation of vitamin E to lipid metabolism. Amer. J. clin. Nutr. 1960, 8, 445 -450 .

Bieri JG, Evarts RP, Thorp S: Factors affecting the exchange of tocopherol between red blood cells and plasma. Amer. J. clin. Nutr. 1977, 30, 686-690.

Bieri JG, Evarts R: Effects of plasma lipids levels and obesity on tissue stores of $\alpha$-tocopherol. Proc. Soc. exp. Biol. Med. 1975, 14, 500-502.

Cunningham JJ, Soares JH: Erythrocyte ghost tocopherol levels in chicks deficient in vitamin E. Nutr. Rep. Inter. 1981, 23, 205-211.

Dunn OJ, Clark VA: In: Applied Statistical Analysis of Variance and Regression. 1st ed. John Wiley \& Sons, New York 1974, pp. 62-86, 132-146.

Epstein E, Baginski ES, Zak B: Extraction of lipids from serum and measurement of total serum lipids. Ann. clin. Lab. Sci. 1972, 2, 244 254.

Finny DJ: In: Statistical Method in Biological Assay. 3rd ed. Alden Press, Oxford, London 1978.

Gallo-Torres HE: Absorption. In: Vitamin E - A Comprehensive Treatise. Basic and clinical Nutrition. (L. J. Machlin, editor). Marcel Dekker Inc. New York and Basel 1980, I, 193-267.

Hakkarainen J, Työppönen J, Jönsson L: Vitamin $E$ requirements of the growing rat during selenium deficiency with special reference to selenium dependent and selenium independent glutathione peroxidase. J. Vet. Med. A. 1986, 33, 247-258. 
Hakkarainen RVJ, Työppönen JT, Hassan $S$, Bengtsson SG, Jönsson SRL, Lindberg PO: Biopotency of vitamin $E$ in barley. Brit. J. Nutr. 1984, 52, 335-349.

Hassan S, Hakkarainen RVJ, Lindberg PO: Bioavailability to chicks of selenium in wheat and fish meal. J. Vet. Med. A. 1987, 34, 353363.

Hassan S, Jönsson L, Hakkarainen J: Morphological studies on nutritional encephalomalacia in chicks, with special reference to mineralized deposits in the cerebellum. J. Vet. Med. A. $1985,32,662-675$.

Hoekstra WG: Biochemical function of selenium and its relation to vitamin E. Fed. Proc. 1975, 34, 2083-2089.

Horwitt MK, Harvey CC, Dahm CH, Searcy MT: Relationship between tocopherol and serum lipid levels for determination of nutritional adequacy. Ann. N. Y. Acad. Sci. 1972, 203, 223-236.

Ishibashi $K$, Abe K, Ohmae M, Kawabe Y, Katsui $G$ : Determination of tocopherols in red blood cells by high speed liquid chromatography. Vitamins 1977, 51, 415-422.

Kaludin I: Tocopherol contents of serum and erythrocytes in rabbits made anemic by bleeding. Int. Z. Vitaminforsch. 1963, 33, 443-451.

Lehmann J: Comparative sensitivities of tocopherol levels of platelets, red blood cells, and plasma for estimating vitamin $E$ nutritional status in the rat. Amer. J. clin. Nutr. 1981, 34, 2104-2110.

Lehmann J: Tocopherol content of platelets and red blood cells as measures of vitamin $E$ status in the rat: Effects of corn oil and lard at two levels. Nutr. Rep. Inter. 1984, 30, 899-906.

Mino M, Kasugai O, Shimizu T: Red blood cell tocopherol and liver tocopherol in hyperlipemic rats as compared with plasma tocopherol. Lipid. 1985, 20, 488-491.

Mino M, Kitagawa $M$, Nakagawa S: Changes of alpha-tocopherol levels in red blood cells and plasma with respect to hemolysis induced by dialuric acid in vitamin E-deficient rats. $J$. Nutr. Sci. Vitaminol. 1981, 27, 199-207.

Mino $M$, Nishida $Y$, Kijima $Y$, Iwakoshi $M, N a-$ kagawa $S$ : Tocopherol level in human blood cells. J. Nutr. Sci. Vitaminol. 1979, 25, 505516.

Noguchi T, Cantor AH, Scott ML: Mode of action of selenium and vitamin $E$ in prevention of exudative diathesis in chicks. J. Nutr. 1973, 103, 1502-1511.

Peake IR, Windmueller HG, Bieri JG: A comparison of the intestinal absorption, lymph and plasma transport, and tissue uptake of $\alpha$ - and $\gamma$-tocopherols in the rat. Bioch. et Bioph. Acta 1972, 260, 679-688.

Poukka RKH, Bieri JG: Blood $\alpha$-tocopherol, erythrocyte and plasma relationships in vitro and in vivo. Lipids 1970,5 , 757-761.

Pudelkiewics LZ, Materson LD, Potter LM, Webster L, Singsen EP: Chick tissue-storage bioassay of alpha-tocopherol: Chemical analytical techniques, and relative biopotencies of natural and synthetic alpha-tocopherol. J. Nutr. 1960, 71, 115-121.

Rose CS, Gyorgy P: Tocopherol requirements of rats by means of hemolyses test. Proc. Soc. exp. Biol. Med. 1950, 74, 411-415.

Scott ML, Desai ID: The relative anti-muscular dystrophy activity of the $d$ - and l-epimers of $\alpha$-tocopherol and of other tocopherols in the chick. J. Nutr. 1964, 83, 39-43.

Statistical Analyses System: User's Guide, SAS Institute Inc., Cary, North Carolina 1985.

Stump DD, Roth EF, Gilber H: Simultaneous determination by high-performance liquid chromatography of tocopherol isomers, $\alpha$-tocopheryl quinone, and cholesterol in red blood cells and plasma. J. Chromat. 1984, 306, 371-376.

Työppönen J, Hakkarainen J, Juokslahti $T$, Lindberg $P$ : Vitamin E requirement of mink with special reference to tocopherol composition in plasma, liver and adipose tissue. Amer. J. vet. Res. 1984, 45, 1790-1794.

Vatassery GT, Krezowski AM, Eckfeldt JH: Vitamin $\mathrm{E}$ concentrations in human blood plasma and platelets. Amer. J. clin. Nutr. 1983, 37, 1020-1024.

Yang NYJ, Desai ID: Effect of high levels of dietary vitamin $E$ on liver and plasma lipids and fat soluble vitamins in rats. J. Nutr. 1977, $107,1418-1428$. 


\section{Sammanfattning}

Inverkan av dietärt E-vitamin på E-vitamininnehållet $i$ helblod, erythrocyter och blodplasma hos kycklingar.

E-vitaminnivåerna $\mathrm{i}$ helblod, röda blodkroppar och plasma hos kycklingar supplementerade stegvist med $0.0,5.0,10.0,20.0$ och $30.0 \mathrm{mg} \mathrm{dl}-\alpha-$ tokoferylacetat $/ \mathrm{kg}$ foder bestämdes $\mathrm{i}$ syfte att studera dessa parametrars användbarhet som kriterier för E-vitaminstatus. Ökningen av E-vitaminhalten var signifikant och lineär $i$ helblod $(r=$ $0.90)$, röda blodkroppar $(r=0.89)$ och plasma $(r=$ 0.93 ) i förhållande till E-vitaminintaget. Det förelåg ett nära samband mellan E-vitaminhalten $\mathrm{i}$ plasma och helblod $(r=0.90)$, plasma och röda blodkroppar $(r=0.91)$ samt helblod och röda blodkroppar $(r=0.95)$. Plasma E-vitaminhalten var 1.2-1.8 gånger och 6.6-12.5 gånger större än i helblod resp. i röda blodkroppar. Halten av totalfett $i$ plasma påverkades inte av dietärt intag av E-vitamin, medan E-vitaminhalten i plasmafettet ökade signifikant med stigande E-vitaminsupplementering. Alfa-tokoferol var den dominerande isomeren (ca $92 \%$ ) i helblod, röda blodkroppar och plasma hos kycklingar vid kläckning. Små mängder av isomererna $\beta$-tokoferol (ca $2 \%$ ), $\gamma$ tokoferol (ca $5 \%$ ) och $\alpha$-tokotrienol (ca $1 \%$ ) observerade vid 1 dags ålder hade minskat eller helt försvunnit vid 7 dagars ålder efter utfodring med E-vitaminfri basdiet. Resultaten visade, att hos kycklingar var E-vitaminhalterna $\mathrm{i}$ helblod och $\mathrm{i}$ röda blodkroppar lika känsliga och pålitliga som kriterier för E-vitaminstatus som E-vitaminhalten i plasma.

(Received November 7, 1989; accepted December 11, 1989).

Reprints may be requested from: Saifeldin Hassan, Department of Clinical Nutrition, College of Veterinary Medicine, Swedish University of Agricultural Science, P. O. Box 7023, S-75007 Uppsala, Sweden. 